\title{
Role of Russia in the International Integration of the Financial Capital
}

\author{
Kotenkova S. N. a \\ Efremov V. A. ${ }^{b}$
}

ab Kazan Federal University, Institute of Management, Economics and Finance, Kazan, 420008, Russia

\section{Doi:10.5901/mjss.2015.v6n1s3p299}

\section{Abstract}

This paper presents the system of calculations which allow find a place of the Russian Federation in the international integration of the financial capital by indicators of export and import which presented in this article. The analysis of trade relationship between 64 countries was conducted to the period from 2001 to 2012 . For the purpose of evaluation of integration processes at the first analysis stage was made matrixes on export and import of goods which were further transformed to the partner matrix reflecting 16 types of trade interaction between two countries. From 2005 to 2012 increase number of the economic partners of Russia. In the article was calculated straight index for distribution the countries on extent of influence on process of the international integration of the financial capital.

Keywords: import, export, partner matrix, strength index, center, periphery.

\section{Introduction}

The international integration of the financial capital serves in modern conditions as a factor of strengthening of national welfare in countries, increasing in rates of economic growth, an employment rate and growth of socio-economic indexes. Integration of the financial capital - this movement of the capital between the countries including export, import of the capital and its functioning abroad also represents objective economic process when the capital leaves economy of one country for obtaining higher income in other country. [3,4]

Rapid growth in the last decades of international trade of the different countries all over the world was followed by rapid development of the international market of the capital which promotes growth of world economy. One of the main indicators of integration of the financial capital is export and import of goods between the countries. Also investments, cross-border bank operations belong to such indicators. However in modern conditions the most of underdeveloped countries depend on the economies which were more developed. High diversification of levels of economic development is observed.

Process of the international integration of the capital has essential impact on economic development of Russia for which typically huge volumes of export of natural resources to many countries in the world. In connection with what it is necessary to define a place of Russia in system of the international streams of the financial capital.

\section{Review of Literature}

Different economists in their treatises were analyzing the effects of the integration of financial capital. Lothian J.R. in his studies paid attention to the development of a framework for the analysis of the effects of the financial integration. [10] Arnoldb I. J.M., Chena J., Ewijka van S.E. and Hnatkovska V.V. evaluated the effect of the flow of financial capital to the economy of the country-participant in financial integration. $[2,6,8]$. In the theory of the world system analysis a great attention is paid to the effects of economic and closely related to them financial integration. It is necessary to notice the treatises of Changhua Y., which are devoted to the study of "center-periphery" countries' interaction. [5] The impact of the economies of developed countries-"centers" on the economy of underdeveloped countries-"peripheries" was studied in the work of Dos Santos, T. [7]. Among the methods determining the effect of a single country to the process of international integration we should note the method of Valentin Piana, which is based on the analysis of international integration in terms of exports and imports. [1,11] Worth noting that foreign scientists in their studies have not paid much attention to Russia and to analysis of its' integration with the CIS countries. 


\section{Method}

Basis for this calculation was taken as a method of constructing a model matrix of integration indicators of financial capital, such as export and import.[9]

At the first stage of the analysis identified the countries that have trade relations with Russia. Then the list of countries was expanded to 64 through the inclusion of key partners on export and import partner countries of Russia.

Next was built matrix of export and import for each country in the line is a binary variable equal to (1) for the five major partner countries and (0) for the other countries. In that way this matrix allows to determine, for each of the countries the main directions of integration of the capital.

The second step we made matrix binary descriptions of the trade relationships between countries. This matrix was built on the Foundation of the analysis of two structural matrices for export and import respectively. Relations between the two countries may correspond to 16 different models of relations. Trade relations between state A and state B can be characterized by four conditions:

1. For $B, A$ is a major export destination

2. For $B, A$ is a major import source

3. For $A, B$ is a major export destination

4. For $A, B$ is a major import source

For each offer, we build a binary variable which will accept value 1 if the statement is right also zero otherwise. "The binary description" of model of two countries can be received, having simply approached four binary variables in the same order as we presented in the relations of the countries of A and B. If the country A cost that for creation of a binary variable across at first we take binary value from a export matrix on crossing of the country $B$ on verticals and the countries of $A$ across, further binary value from structural model on import on crossing of the country of $B$ on verticals and the countries of $A$ across, further from structural model value of the country In across and the countries of $A$ down, and from import value of the country In across and the countries And down.

As a result we receive 16 types of interaction between the countries: 0000 - the countries "ignore" each other; 0001 - $B$ is an important provider for $A ; 0010$ - $B$ is an important market for $A ; 0011$ - B is very important to $A$, but the reverse is not true; 0100 - $A$ is an important provider of $B$, but $A$ can ignore $B ; 0101$ - They both need each other as providers; 0110 - One flow is important for both: the exports of $A$ to $B ; 0111$ - $A$ depends on $B$, but $B$ needs $A$ 's supply as source; 1000 - $A$ is an important destination for $B$, while $A$ can ignore $B$; 1001- One flow is important for both: the exports from $B$ to $A ; 1010$ - They both need each other as exporters; 1011- A depends on B, but $B$ needs A market as destination; 1100 $A$ is very important to $B$ and can afford to ignore it; $1101-A$ is very important to $B$ but $A$ needs $B$ as a source $1110-A$ is very important to $B$ but $A$ needs $B$ as a destination; 1111 - They need each other on an equal foot.

Then, the number of connections for each type of interaction was determined. The formula that avoids duplication, considering the specificity of the model matrix's construction, was used for the interaction with types 0000; 1111; 1010; 0101.

$N_{b d r}=N_{b d} / 2(1)$

where $N_{b d}$ - the number of links, $N_{b d r}$ - the real number of links formula.

At the final stage, the Strength-index was calculated for each country in the dynamics according to the following

$I_{p}=N_{b d}{ }^{*} I_{p c o d e}+N_{b d}{ }^{*} I_{p c o d e} \cdot . . .(2)$

where $N_{b d}$ is the number of binary descriptions of trade relations, $I_{\text {pcode }}$ - the code of Strength-index in concordance with the binary description of trade relationships. (Table 1)

Table 1. Codes of binary description.

\begin{tabular}{|l|c|c|c|c|c|c|c|c|c|c|c|c|c|c|c|c|}
\hline Binary description & 0000 & 0001 & 0010 & 0011 & 0100 & 0101 & 0110 & 0111 & 1000 & 1001 & 1010 & 1011 & 1100 & 1101 & 1110 & 1111 \\
\hline Strength score & 0 & 2 & 2 & 1 & 6 & 4 & 4 & 3 & 6 & 4 & 4 & 3 & 7 & 6 & 5 & 4 \\
\hline
\end{tabular}

\section{Results}

This method of analysis of the integration of financial capital in terms shows the asymmetric structure of relations between the countries. The dynamics of the global partnership is characterized by the absence of a two-way relationship: Share of relationships by type 0000 was $82 \%$ for 2001, 2010, 2012, 81\% in 2005 from all trade relations during the period under review. Binary description, which means dominance of the countries, without any lack of relationship, weak 
dominance (two types) of $27 \%$ and $25 \%$ of $2005,29 \%$ and $25 \%$ in $2010,28 \%$ and $25 \%$ in 2012 , whereas the symmetric integration - $6 \%$ in $2001,5 \%$ in 2005, 2010, 2012. Which indicates an increase between integrable countries and it has a negative effect on international flows of financial capital. (Figure 1)

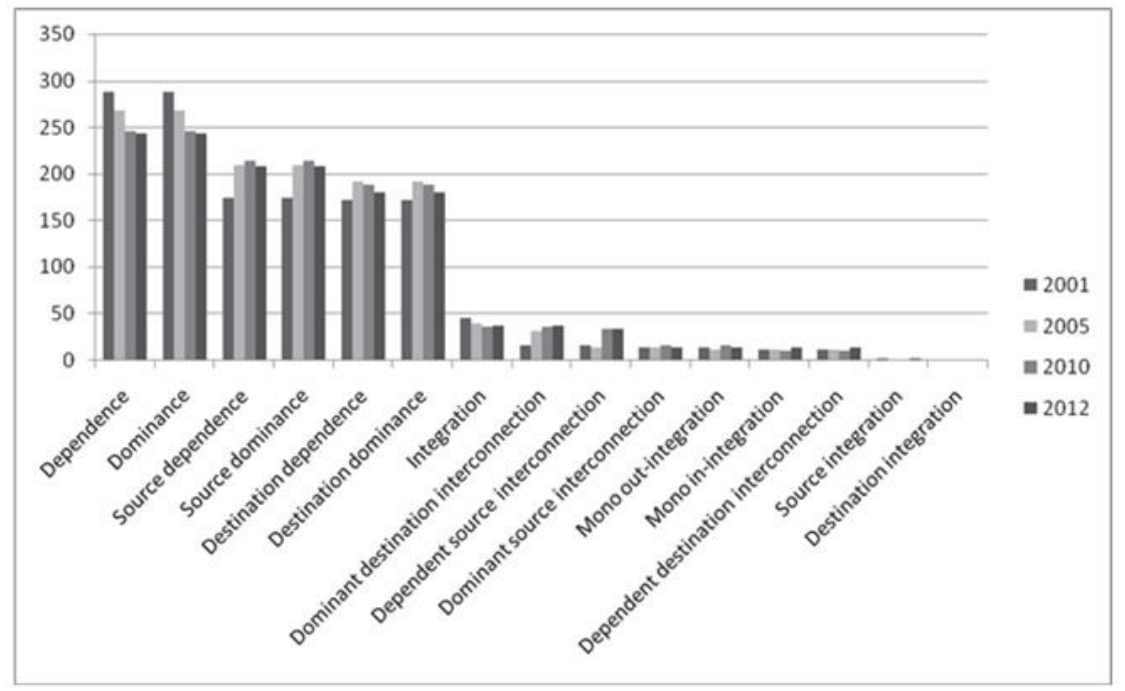

Figure 1. Structure of partnerships.

Analyzing the performance of the Strength-index during the period from 2001 to 2012, we can conclude that more points of integration in terms of exports and imports appeared. This analysis does not take into account some of their main partner countries, but due to its insignificance in the international arena, it did not affect the overall picture arrangement in the world. USA and Germany are based on a hierarchical system, where in 2001 the US has 385 on a scale of Strengthindex, Germany - 432 in 2005, in 2010 the US -313, Germany - 370, in 2012 the US - 321, Germany - 370 (Figure 2)
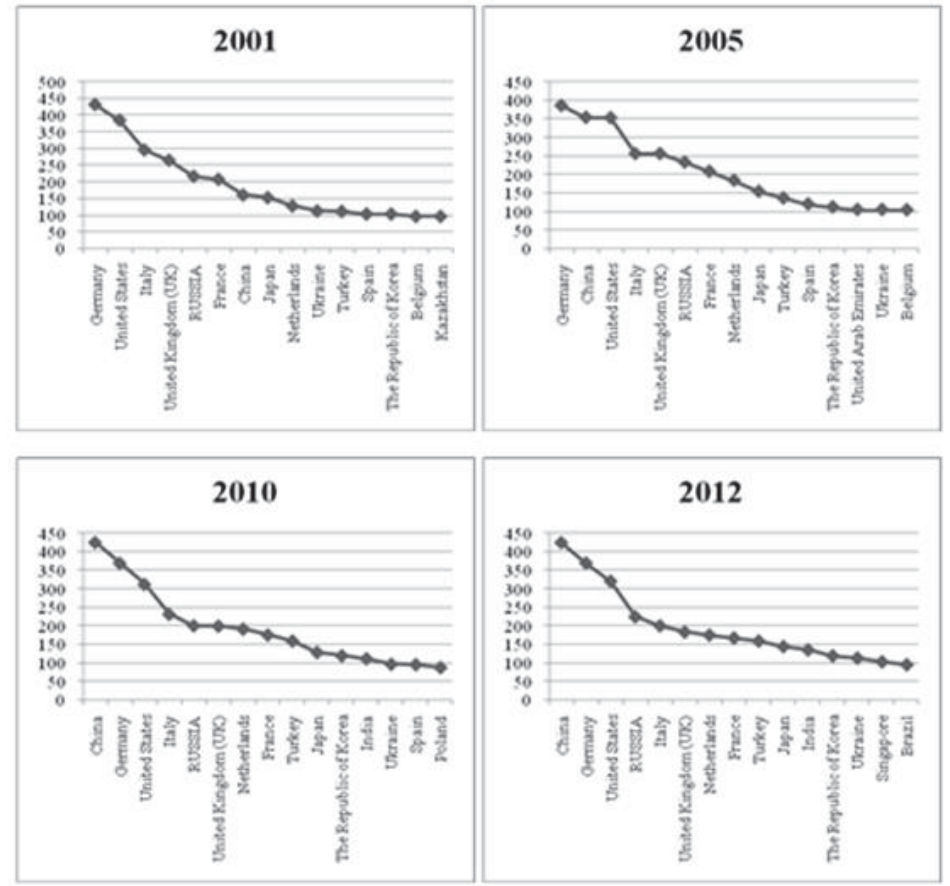

Figure 2. Strength indexes of top 20. 
It is worth noting that during the analyzed period, China ranked first world exporter. As well as Republic of Korea showed a high rate of growth in terms of exports.

As for Russia, from 2001 to Russia of 2005 showed a positive dynamics of the Strength-index from 217 to 233 points, from 2005 to 2010 fall to 201, and in 2012 again there is a positive trend. Analyzing the binary values of Russia in the model matrix from 2001 to 2005, there was a mutual integration of financial capital with Ukraine and Belarus. In 2010 and 2012 there is an overall increase of relations with all countries, the share of energy exports to Europe is growing, as well as it is observed that Russia is a center for the integration of the CIS countries. (Table 2)

Table 2. The dynamics of integration relations of financial capital of the Russian Federation.

\begin{tabular}{|l|c|c|c|c|c|}
\hline Name & & 2001 & 2005 & 2010 & 2012 \\
\hline Absence of relationships & 0000 & 72 & 68 & 76 & 70 \\
\hline Source dependence & 0001 & 10 & 14 & 9 & 12 \\
\hline Destination dependence & 0010 & 4 & 2 & 2 & 1 \\
\hline Dependence & 0011 & 10 & 11 & 12 & 12 \\
\hline Source dominance & 0100 & 10 & 14 & 9 & 12 \\
\hline Source integration & 0101 & 0 & 0 & 0 & 0 \\
\hline Mono out-integration & 0110 & 0 & 0 & 0 & 1 \\
\hline Dependent source interconnection & 0111 & 1 & 1 & 1 & 1 \\
\hline Destination dominance & 1000 & 4 & 2 & 2 & 1 \\
\hline Mono in-integration & 1001 & 0 & 0 & 0 & 1 \\
\hline Destination integration & 1010 & 0 & 0 & 0 & 0 \\
\hline Dependent destination interconnection & 1011 & 0 & 0 & 1 & 1 \\
\hline Dominance & 1100 & 10 & 11 & 12 & 12 \\
\hline Dominant source interconnection & 1101 & 1 & 1 & 1 & 1 \\
\hline Dominant destination interconnection & 1110 & 0 & 0 & 1 & 1 \\
\hline Integration & 1111 & 4 & 2 & 0 & 0 \\
\hline Strength Index & & 217 & 233 & 201 & 225 \\
\hline
\end{tabular}

\section{Conclusion}

To summarize, we can conclude that the relationships related by the integration of financial capital are rapidly evolving; the poles of integration are changing. The dynamics of growth of exports from China and the Republic of Korea can be an example of this point. The positions of the United States and Germany as the integration centers are strengthening. Russia showed a positive trend in the growth rate of integration ties in the world for the period from 2001 to 2012, thereby strengthening its position in the post-Soviet space and with a number of other countries.

\section{References}

Albert A., Barabasi A. L., Statistical Mechanics of Complex Networks // Reviews of Modern Physics, 2002, pp. 7428.

Gallyamova D. Kh. Development of Globalization in the Modern Economy // World Applied Sciences Journal 30 (9): 1160-1165, 2014.

Arnoldb I. J.M.. Ewijka van S. E., Financial integration in the euro area: Pro-cyclical effects and economic convergence // Economic Modelling, 2014 Y.

Centeno M., Curran S. R., Galloway J., Lloyd P., \& Sood S., Growing Knowledge about Globalization (GKG), Observing Trade, 19802001, // Presentation at the Institute for the Study of the Americas (University of London), September 2005

Centeno M., Global Flows of Information presented at the Conference "Global Flows of Information" organized by Yale Law School , April 2005

Changhua Y., Evaluating international financial integration in a center-periphery economy //Journal of International Economics, 2014

Chena J, Quangb T., The impact of international financial integration on economic growth: New evidence on threshold effects. Volume 42, october 2014, pp.475-489

Razumovskaya, E.M., Mishakin, T.S., Popov, M.L., Kucevol, N.G. Medical services during the XXVII world summer universiade 2013 in Kazan. Mediterranean Journal of Social Sciences, Volume 5, Issue 18 SPEC. ISSUE, 2014, Pages 17-20.

Glebova I.S., Yasnitskaya Ya.S., Maklakova N.V. Possibilities of "Smart City" Concept Implementing: Russia' s Cities Practice/l Mediterranean Journal of Social Sciences.- Vol.5, No12, (2014)-pp.129 - 133.

Dos Santos, T., The Crisis of Development Theory and the Problem of Dependence Latin America // Underdevelopment and Development., 1976 pp. 59

Hnatkovska., V. V. M. D.D. Evans International capital flows, returns and world financial integration //Journal of International Economics. Volume 92, Issue 1, 2014, pp.14-33 
International trade center, trade statistics, Export Import by country in 2001-2012.

Gibadullin, M.Z., Fazlieva, E.P., Nurieva, A.R., Grigoryeva, L.L. Territorial aspects of migration processes in Russia. Mediterranean Journal of Social Sciences, Volume 5, Issue 12, June 2014, Pages 93-96.

Lothian J. R., Institutions, capital flows and financial integration // Journal of International Money and Finance. Volume 25, Issue 3, April 2006, pp. 358-369

Glebova, I., Khabibrakhmanova, R., Yasnitskaya, Y. The analysis of the impact of the investment attractiveness factors of the region on the fixed capital investments in the economy of the Republic of Tatarstan // Middle East Journal of Scientific Research 17 (10), pp. 1498-1502,-2014.

Piana V. The "pattern approach" to world trade structures and their dynamics // Economics Web Institute. March 2006

Razumovskaya, E.M. , Kutsevol, N., Popov, M., Mishakin, T., Leto, L., Tsalikova, V. The effectiveness of management practice in the market of socially important services, Asian Social Science, Volume 10, 28 September 2014, Pages 118-122

Nurieva, A.R., Gibadullin, M.Z., Fazlieva, E.P. Stability of interregional trade and economic relations as the factor of competitiveness of territories, World Applied Sciences Journal, Volume 29, Issue 4, 2014, Pages 501-505 